\title{
A Interação Verbal: as Atividades de Apropriação e de Objetivação
}

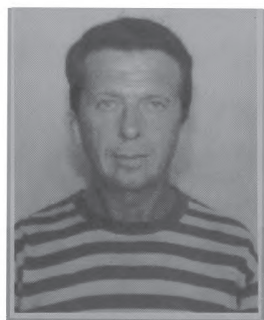




\title{
Resumo
}

O presente texto busca refletir sobre as atividades da interação verbal que são constitutivas da subjetividade do individuo, enfatizando o que se convencionou chamar de determinações sociais, e, ao mesmo tempo, desconstruindo a idéia de que elas conduzem à anulação da singularidade, ou seja, da individuação.

\section{Palavras-chave}

interação, discurso, subjetividade.

\begin{abstract}
This text aims to study the verbal interaction activities which constitute the individual's subjectivity, emphasizing what is conventionally called social determinations, and, simultaneously, deconstructing the idea that these activities lead to the annuling of the singularity, or, better speaking, of the individuality.
\end{abstract}

\section{Key words}

interaction, discourse, subjectivity. 


\begin{abstract}
A interação verbal, assim como a assumo, se explicita a partir da concepção de que a linguagem simbólica, quando acionada, implica em que os indivíduos realizam determinadas atividades que são constitutivas da subjetividade, entendida como processo de individuação. São, basicamente, dois os tipos de atividades que os interlocutores realizam na interação verbal: a enunciação e a apreensão do enunciado.

Pretendo construir, aqui, uma reflexão sobre essas atividades, considerando-as, respectivamente, uma objetivação e uma apropriação. $\mathrm{E}$, ao eleger esses dois conceitos, faço-o na suposição de que possam ser mais produtivos do que os primeiros na explicação do que ocorre na interação verbal.

Escolho, como ponto de partida, a idéia de que se o signo lingüístico é genérico e, por isso, também generalizante, então é precisamente essa dimensão da linguagem que se constitui, uma vez, como condição de sociabilidade do indivíduo: o homem só se constitui, historicamente, como ser social porque a linguagem simbólica, como mediação, viabiliza isso. Estou afirmando que a linguagem simbólica, pelas atividades que realizam seus usuários e que decorrem de suas características, implica em processos de socialização. Ela se faz condição fundamental para a atividade interativa na sociedade.
\end{abstract}

A sociabilidade torna-se, então, não apenas um traço a mais do 
homem, mas uma dimensão vital: a passagem histórica que conduziu à socialização representa um momento definitivo que não admite nenhuma volta a um estágio anterior, ou seja, a um ser-fora-da sociedade, o que não deverá, porém, levar a que se entenda que, em função dessa determinação, o indivíduo não apresente mais nenhuma característica de singularidade, apenas genericidade. A linguagem simbólica, ao mesmo tempo que conduz ao processo de socialização do homem, leva também a que ele não seja apenas um resultado das determinações sociais. $E$ isso pode ser observado no processo de interação verbal: as atividades com uma mediação com as características da linguagem simbólica conduzem, paradoxalmente, à constituição de duas dimensões do homem, entendido como ser social e como ser singular.

Para poder explicitar esse aparente paradoxo, busco apoio numa afirmação de Duarte e que coloca a questão da genericidade e da singularidade do homem:

A atividade vital é aquela que reproduz a vida, é aquela que toda a espécie animal (e também o gênero humano) precisa realizar para existir $e$ reproduzir a si própria enquanto espécie. [...] A atividade vital é a base a partir da qual cada membro de uma espécie reproduz a si próprio enquanto ser singular e, em conseqüência, reproduz a própria espécie. No caso do ser humano, a mera sobrevivência física dos indivíduos e sua reprodução biológica através do nascimento de seres humanos, assegura a continuidade da espécie biológica, mas não assegura a reprodução do gênero humano, com suas características historicamente constituídas. A atividade vital humana não é apenas uma atividade que assegura a sobrevivência do indivíduo que a realiza

Significação $13 \quad 230$ 


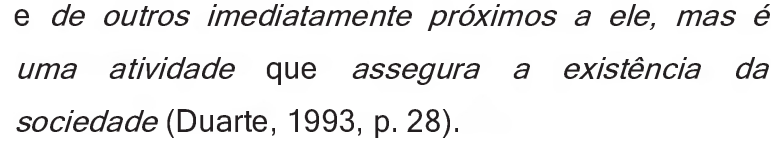

Essa atividade vital, que faz - e se faz - História, constitui-se, precisamente por ser histórica, de dois processos que realiza o individuo e que o constituem como singularidade, e, ao mesmo tempo, como parte da genericidade: a apropriação que ele realiza do que o género humano produziu, e a objetivação que se constitui no processo de socialização do que ele passa a produzir a partir do que se apropriou e do que reelaborou. Assim, primeiro, o homem se insere no social, apropriando-se do que está posto e instituido, para depois, completando o processo de socialização, passara participar da construção do social e de sua História.

O indivíduo, contudo, ao se inserir no social e na História como um ser genérico/humano, nunca o faz como se realizasse um processo de justaposição do exterior para o interior: a noção de apropriação envolve sempre a de transformação porque o discurso através do qual se realiza a apropriação tem a característica de ser incompleto, e, por isso, possibilidade de atividade do sujeito, atuando e singularizando o que é genérico.

Parece que a concepção de que o homem ao se construir, ao mesmo tempo, como singularidade e genericidade, dando formas a sua consciência, num processo que vai do exterior para o interior, pode conduzir à noção de acumulação por justaposição dos elementos culturais do gênero humano. O fato, porém, de essa apropriação se realizar vía linguagem simbólica determina uma conseqüência que é radicalmente humana, e que conduz à construção da singularidade: a ¡ncompletude de sentido do signo significa urna falta que os grupos e os individuos preenchem através das atividades diferenciadas e singulares.

A apropriação não é, pois, um processo em que o indivíduo se faz proprietário em definitivo como ser singular: ele toma posse de um produto

Significação $13 \cdot 231$ 
social, mas isso não significa que seja o único proprietário. O direito de posse é partilhado com todos os que convivem com ele no grupo e na sociedade. Em outras palavras, a apropriação que é conduzida pela linguagem simbólica não pode implicar em algo parecido com a idéia de "propriedade privada", mas com a de um bem coletivo. A linguagem simbólica, pois, é produto e, ao mesmo tempo, instituinte da dimensão singular e social do homem, porque, se oferece o espaço para a atividade singularizante, também cria o vínculo irremovível com o bem coletivo.

Um bem coletivo só é propriedade do indivíduo enquanto este for membro aceito e incluído numa comunidade, pois qualquer produto da atividade humana, uma vez objetivado através da linguagem, torna-se significativo e referência para os indivíduos não apenas como seres singulares, mas também sociais.

Essa concepção leva, pois, à conclusão de que, se é do exterior que se constitui a consciência do homem, a sua singularidade se deve à incompletude da linguagem simbólica através da qual se realiza a apropriação. O homem é único, é diferente, porque a sua consciência, junto a qual atuam também as emoções, as sensações, no processo de apropriação se torna única e diferenciada porque o desejo, ao buscara completude onde há a falta, conduz ao singular. E nessa tarefa permanente - sempre ilusória e provisória - constrói-se a singularidade do homem.

A singularidade da consciência é, pois, resultado da apropriação singular do genérico: preenchendo a falta de sentido, a consciência organiza, para si, um sistema social e também próprio de referência que vai interferir e orientar as sucessivas e futuras apropriações, sempre com maiores e melhores condições de singularização. É um sistema de interpretação que se cria e que condiciona a apropriação e faz com que ela sempre represente uma transformação, ou seja, uma reelaboração. $O$ impulso que move a consciência nessa atividade, contudo, não é só do nível da razão, mas também, e especialmente, do desejo que a incompletude - que é carência de sentido - faz emergir

Significação $13 \cdot 232$ 
Como a realidade social se apresenta heterogênea e os sistemas de referência necessariamente ostentam contornos diferenciados porque a sua produção é determinada pela diversidade cultural, a forma da consciência, à medida em que estabelece, através da linguagem, as interações com essa diversidade, sofrerá maiores ou menores influências dessa heterogeneidade simbólica. E isso será de uma importância fundamental porque, ao se constituir na heterogeneidade, a consciência vai ampliando, a cada apropriação, a sua capacidade, o seu grau de alcance e a abrangência das interpretações. Em outros termos, quanto mais heterogêneos forem os componentes do sistema de interpretação da consciência, tanto maior será o seu grau de percepção e de compreensão do real.

O processo de apropriação, pois, via linguagem simbólica, dá condições a que se constitua, ao mesmo tempo, a singularidade do homem e a sua genericidade, constituindo-se como um momento especial do mesmo modo que a objetivação, a qual se traduz como um segundo acontecimento de singularização e de socialização.

A objetivação é a exteriorização (ou socialização) daquilo que o indivíduo produziu a partir da apropriação e da sua atividade reelaborativa, e coloca uma nova questão: o produto é único, mas a linguagem simbólica - de caráter generalizante - que servirá de mediação para a sua socialização, é incapaz de oportunizar a partilha de sentidos singulares. Cabe, então, ao enunciante, agora como singularidade que objetiva, alocar e trabalhar os recursos lingüísticos e discursivos que the são colocados à disposição pela coletividade, de forma que aquilo que é seu, singular, possa vir a se integrar no instituído socialmente. É, portanto, um novo momento de socialização do homem.

Se, na apropriação, o indivíduo se socializa ao assumir o que está posto, na objetivação ele oferece o resultado de sua atividade transformadora e elaborativa como contribuição e participação na construção do instituído que sustenta a sociedade.

Evidentemente, essa tarefa não é nada fácil: requer que o enunciante 
acione o sistema de referência de que se apropriou e construa com ele uma ou várias, mesmo inúmeras, tentativas de aproximação com os sentidos genéricos/singulares de seus interlocutores. O sucesso maior ou menor depende (como também no caso da apropriação) da capacidade e do alcance maior ou menor do sistema de referência que alimenta as operações da consciência. E, por isso, embora o discurso se faça ponte que permite e, ao mesmo tempo, limita o acesso à realidade social, tanto a apropriação como a objetivação, ao caracterizarem uma maior ou menor capacidade de percepção do real, levam à concepção de graus de subjetividade. O discurso, produto-mediação de e para uma heterogeneidade social, oferece àquele que tiver uma consciência mais desenvolvida a incompletude como uma possibilidade de atuação e participação mais ampla e profunda.

$\mathrm{Na}$ interação verbal, pois, os processos de apropriação e objetivação representam, sempre, uma transformação da realidade: o receptor, ao se apropriar das objetivações dos membros de sua comunidade, pelo fato de agir com categorias de interpretação que são, uma vez, sociais, mas também singulares, altera o objeto de que se apropriou. Da mesma forma, o indivíduo, ao enunciar, convida os seus interlocutores à apropriação do que produziu, o que nunca poderá ser um processo de sucesso pleno, precisamente, porque a apropriação implica em transformação.

A inserção, pois, do indivíduo na sociedade, através da linguagem mediação na apropriação e na objetivação-, caracteriza duas atividades diferenciadas, mas vitais: uma que é a de manter o instituído que garantiu a sociabilidade até o momento, e outra que é a de reelaborar o instituído tendo em vista que isso é vital diante das modificações de ordem histórica a que conduzem as consciências singulares em interação. E quando se fala de manutenção e reelaboração do instituído, evidentemente também se faz referência à linguagem: a atividade dos indivíduos singulares, premidos pela falta e a incompletude do signo simbólico, também, passa a produzir, embora lentas, transformações na mediação utilizada.

Significação $13 \quad 234$ 
A socialização do indivíduo significa, pois, também um processo de singularização, mas que não se realiza frente a algo amorfo e imóvel: tanto a apropriação como a objetivação ocorrem sempre em presença do que está posto, do universo social onde outros indivíduos estão envolvidos em atividades semelhantes. O sujeito, então, não se constitui só. O simbólico que impõe a atividade de preenchimento da incompletude que pertence é o genérico, o faz sempre na presença do Outro. Assim, a atividade do indivíduo precisa levar em consideração as atividades dos outros, o que define a construção da subjetividade como um processo, concomitantemente, individual e social.

E é nessa tensão entre o que é de ordem do individual e do social, entre o singular e o coletivo, entre um interior e um exterior, que se realiza a interação verbal.

Ela se processa na tensão que se estabelece entre o genérico e o singular, entre o instituído e o novo, entre o posto e a falta, precisamente porque o que faz do homem um ser singular e social é uma mediação cujas características são constitutivas dessa dualidade. O que é do nível do singular, ${ }^{1}$ quer pertença a determinados segmentos da sociedade, quer ao indivíduo, está, pois, presente na interação verbal, e podem levar os interlocutores a perceberem, às vezes com mais, outras com menos clareza, as diferenças que emergem como dificuldades ou mesmo como geradoras de conflito. E quando se dá a imposição de um excedente de sentido, isso significa sempre um ato autoritário, ou seja, um exercício de poder no cerceamento da autonomia de um dos indivíduos envolvidos na interação.

A interação verbal, contudo, quando fica afastada essa situação de imposição autoritária, pode conduzir à reformulação do que é o genérico instituído que tanto pode pertencer a um certo segmento social ou a toda a sociedade.

1. Como o que é singular traduz um preenchimento da incompletude do sentido genérico, ele pode ser considerado um excedente de sentido. 


\section{Bibliografia}

DuARTE, N. 1993. A individuação para-si. Campinas: Autores Associados.

Significação $13 \quad 236$ 